\title{
Physicochemical and Health Promoting Properties of Everbearing Strawberry Cultivar, 'Dekoruju' Berries
}

\author{
Takeshi Nagai $^{1,2,3}$, Norihisa Kai ${ }^{4}$, Yasuhiro Tanoue ${ }^{5} \&$ Nobutaka Suzuki $^{6}$ \\ ${ }^{1}$ Graduate School of Agricultural Sciences, Yamagata University, Yamagata, Japan \\ ${ }^{2}$ The United Graduate School of Agricultural Sciences, Iwate University, Iwate, Japan \\ ${ }^{3}$ Graduate School, Prince of Songkla University, Songkhla, Thailand \\ ${ }^{4}$ Graduate School of Engineering, Oita University, Oita, Japan \\ ${ }^{5}$ National Fisheries University, Yamaguchi, Japan \\ ${ }^{6}$ Nagoya Research Institute, Aichi, Japan \\ Correspondence: Takeshi Nagai, Graduate School of Agricultural Sciences, Yamagata University, Yamagata \\ 9978555, Japan. Tel: 81-235-28-2821. E-mail: nagatakenagatake@yahoo.co.jp; tnagai@tds1.tr.yamagata-u.ac.jp
}

Received: May 9, 2018

doi:10.5539/jas.v10n8p15
Accepted: June 8, $2018 \quad$ Online Published: July 15, 2018

URL: https://doi.org/10.5539/jas.v10n8p15

\begin{abstract}
Overall appearance on everbearing strawberry cultivar, 'Dekoruju' berries were observed. Berries were glossy and colors of skins and pulps were favorable (red-fleshed). An eating quality was good and berries had a favorable balance of sweetness and sourness because of higher sugar-acid ration (14.6) of berries. Berries were foods rich in vitamin $B_{1}(0.35 \pm 0.02 \mathrm{mg} / 100 \mathrm{~g} \mathrm{FW})$ and phenol compounds $(80.4 \pm 0.6 \mathrm{mg} / 100 \mathrm{~g} \mathrm{FW})$ such as anthocyanins and flavonoids. Extracts prepared from berries, especially in $100 \%$ concentration, almost completely inhibited linoleic acid peroxidation under the condition tested. These showed extremely high scavenging activities against specially superoxide anion $(92.2 \pm 2.16 \%)$ and DPPH $(>100 \%)$ radicals in comparison with all commercially available natural or synthetic antioxidants tested. These also exhibited the foremost inhibitory activities against not only ACE $(62.7 \pm 5.1 \%)$ but also hyaluronidase $(67.6 \pm 3.5 \%)$, suggesting beneficial effects on anti-hypertension, anti-allergy, and anti-inflammatory. The present study indicated that fresh 'Dekoruju' berries may be considered as good sources of natural antioxidants such as phenol compounds (anthocyanins and flavonoids), and may contribute to maintain and promote health and to help protect body against chronic diseases and an allergy disease.
\end{abstract}

Keywords: anti-allergic activity, anti-oxidative activity, chemical analysis, 'Dekoruju' berry

\section{Introduction}

Strawberry (Fragaria x ananassa Duch.) is one of popular and attractive vegetables and is eaten as a fresh fruit and a processing ingredient of products such as cakes, ice cream, jams, juices, yogurts, preserves, and liqueurs. For consumers, not only favorable appearances (particularly red or scarlet color) but also desirable flavor, sweetness, and acidity (sourness) are contributed to their initial impression (Mitcham, 2004). In addition, firmness and skin toughness of berries are very important factors that affect these quality maintenance, transportability, and operability in actual demand. In Japan, strawberry is in demand all year round, and mostly is for fresh market in seasons from winter to spring: the June-bearing strawberry cultivars such as 'Tochiotome', 'Toyonoka' and 'Amaou' are on the commercial sales and distribution. However, there is in great request as business purposes for making cakes in seasons from July to October. Flower-bud differentiation of the June-bearing strawberry is inhibited in a hot long-day environment of summer and autumn. So, strawberry is imported about 4,000-5,000 tons per year from foreign countries such as the United State of America to supply demand in domestic off-seasons (Imada, 2006). It draws the highest attention ever in strawberry of summer-autumn production in Japan to be inferior in freshness, taste and flavor, and firmness of the imported strawberries, and to increase demand against domestic products in consumer market.

Since Ohishi had succeeded to cultivate an everbearing strawberry cultivar, 'Ohishi-shikinari 1' in 1954 (Takahashi, 2006), many everbearing strawberry cultivars have been cultivated one after another not only in 
Japan (variety names: Miyoshi, Summerberry, Everberry, Pechika, Summerprincess, Summerruby, Natsuakari, and Tochihitomi and so on) but also in England (Serenata), the United State of America (Irvine, Seascape, Capitola, Aromas, Gaviota, Diamante, and UC Albion), and the Kingdom of the Netherlands (Eran) (Yui \& Honjo, 2007).

There are many species of everbearing strawberry cultivars, but these characteristics are markedly different according to type of cultivars. Strawberry is an excellent source of nutrients (Sone et al., 1999) and phytochemicals (Yoshida et al., 2002). Especially, phenol compounds in berries possess remarkable antioxidant activity (Basu et al., 2009; Jin et al., 2011; Oszmianski \& Wojdylo, 2009). A large quantity of anthocyanin is contained in berries of strawberry cultivars (Lopes-da-Silva et al., 2007). Among them, pelargonidin 3-o-glucoside $(\mathrm{P} 3 \mathrm{G})$ is the major predominant and is responsible for fascinating red or scarlet color of fresh berries, followed by cyanidin 3-glucoside, pelargonidin 3-rutinoside, pelargonidin 3-succinate (Bakker et al., 1994), pelargonidin 3-galactoside (Kikoku et al., 1995), and pelargonidin 3-malonylglucoside (Tamura et al., 1995) as minor anthocyanins, flavanols as catechins, and flavonols as quercetin and kaempferol glycosides (Cordenunsi et al., 2005; Gil et al., 1997). In the previous study, it had been proved that intake of strawberries contributed to (1) lower risk of cardiovascular by inhibition of LDL-cholesterol oxidation, (2) promote plaque stability, (3) improve vascular endothelial function, (4) decrease tendency for thrombosis, (5) modulate inflammatory process, (6) block initiation of carcinogenesis, (7) suppress progression and proliferation of tumors (Hannum, 2004), (8) inhibit proliferation of human liver cancer cells (Meyers et al., 2003), (9) inhibit esophageal cancer (Stoner et al., 1999), (10) possess anti-carcinogenic activities to breast and cervical cancer cells (Wedge et al., 2001), (11) inhibit growth and stimulation of apoptosis of human cancer cells (Seeram et al., 2006), and (12) inhibit Helicobactor pylori with enhanced susceptibility to clarithromycin (Chatterjee et al., 2004). Intake of fresh fruit as strawberry is believed to have ability to protect human body from some diseases (Huang et al., 2010; Lansky \& Newman, 2007; Opara and Al-Ani, 2010).

An everbearing strawberry cultivar, 'Dekoruju' was selected from hybrid seedlings between a female parent 'Pajaro' (June-bearing strawberry cultivar) and a male parent 'Morioka No.26' (everbearing strawberry one) and was registered in 2007 (Okimura et al., 2011). However, as far as we know, there is still lacking of scientific information about nutritional and functional values in these berries. Main objectives of present study try to investigate chemical parameters, vitamins $\mathrm{B}_{1}, \mathrm{~B}_{2}$, and $\mathrm{C}$, total phenols, flavonoids, and anthocyanins, and to clarify medicinal properties as anti-oxidative activity, anti-hypertensive activity, and anti-allergic activity of berries.

\section{Materials and Method}

\subsection{Samples}

Fresh everbearing strawberry cultivar, 'Dekoruju' berries (weight 12.4-40.3 g, average weight $23.7 \mathrm{~g}$; Figure 1A) were gifted from an independent farmer, Yamagata, Japan, and used in this study.

\subsection{Overall Appearance and Sensory Evaluation}

Overall appearance of fresh berries was observed. Next, sensory qualities of berries were evaluated on the basis of sweetness, sourness, and firmness by a panel of 4 panelists on a 5-point Hedonic scale.

\subsection{Chemical Analysis}

Chemical analysis of everbearing strawberry cultivar, 'Dekoruju' berries was performed. Moisture was measured using a Moisture Determination Balance (FD-600; Kett Electric Laboratory, Tokyo, Japan). Crude proteins were determined by Kjeldahl method using a conversion factor of 6.25. Crude lipids were analyzed by ether extraction. Crude ashes were determined using an electric furnace (AMI-II; Nitto Kagaku Co. Ltd., Aichi, Japan). Carbohydrates were calculated by difference. The $\mathrm{pH}$ was measured using a $\mathrm{pH}$ meter (PHL-40; DKK Co. Ltd., Tokyo, Japan). Sugar content was determined using a refractometer (PAL-Pâtissier; Atago Co. Ltd., Tokyo, Japan). Titratable acid content was measured by neutralization titration, and was expressed as percentage equivalent of titratable citric acid. Total vitamin $\mathrm{B}_{1}$ content was determined by $p$-aminoacetophenone method (Nakamura et al., 1998). Total vitamin $B_{2}$ content was measured by lumiflavin fluorescence method (Nakamura et al., 1998). Total vitamin C was determined by $\alpha, \alpha^{\prime}$-dipyridyl method (The Vitamin Society of Japan, 1990). Total phenols (Slinkard \& Singleton, 1977) and total flavonoids analysis (Kim et al., 2003) was performed by using Folin-Ciocalteu method. These contents were expressed as ellagic acid equivalents and as (+)-catechin equivalent, respectively. Total anthocyanins were measured after an extraction by methanolic hydrochloric solution (1.0\% HCl-methanol) (Oki \& Suda, 2008). The content was expressed as pelargonidin 3-o-glucoside (P3G) equivalent. 


\subsection{Color Measurement}

Color analysis was performed using a colorimeter (NR-11A; Nippon Denshoku Industries Co. Ltd., Tokyo, Japan) with illuminant D65 calibrated to black and white standards. Tristimulus $L^{*} a^{*} b^{*}$ measurement mode was used as the relation to human eye response to color. The $L^{*}, a^{*}$, and $b^{*}$ scales represents lightness, red-green dimension, and yellow-blue dimension, respectively. Color was determined on ten different spots in each and results were shown as the mean of these measurements.

\subsection{Anti-oxidative Activity}

Anti-oxidative activities of extracts prepared from everbearing strawberry cultivar, 'Dekoruju' berries were investigated using a linoleic acid oxidation system described by Nagai and Nagashima (2006). Ascorbic acid, tert-butyl-4-hydroxyanisole (BHA), 2,6-di-t-butyl-4-methylphenol (BHT), $\alpha$-tocopherol, and trolox were used as positive control, and distilled water was used as negative one.

\subsection{Superoxide Anion Radical Scavenging Activity}

Superoxide anion radical scavenging activities of extracts from berries were measured using a xanthine/xanthine oxidase system, as described by Nagai and Nagashima (2006). Ascorbic acid, BHA, BHT, $\alpha$-tocopherol, and trolox were used as positive control, and distilled water was used as negative one. $\mathrm{IC}_{50}$ value was defined as concentration of extract to inhibit $50 \%$ of superoxide anion radical activity. Moreover, activity was also expressed as micromoles of trolox equivalents per $\mathrm{kg}$ of fresh weight of berries [trolox equivalents antioxidant capacity (TEAC); $\mu \mathrm{M} \mathrm{TE} / \mathrm{kg}$ FW].

\subsection{Hydroxyl Radical Scavenging Activity}

Hydroxyl radical scavenging activities of extracts from berries were investigated using a Fenton reaction system, as described by Nagai and Nagashima (2006). Ascorbic acid, BHA, BHT, $\alpha$-tocopherol, and trolox were used as positive control, and distilled water was used as negative one. $\mathrm{IC}_{50}$ value was defined as concentration of extract to inhibit $50 \%$ of the hydroxyl radical activity. Moreover, activity was also expressed as TEAC ( $\mu \mathrm{M} \mathrm{TE} / \mathrm{kg} \mathrm{FW})$.

\subsection{1,1-Diphenyl-2-Picrylhydrazyl (DPPH) Radical Scavenging Activity}

DPPH radical scavenging activities of extracts from berries were performed as described by Nagai and Nagashima (2006). Ascorbic acid, BHA, BHT, $\alpha$-tocopherol, and trolox were used as positive control, and distilled water was used as negative one. $\mathrm{IC}_{50}$ value was defined as concentration of extract to inhibit $50 \%$ of DPPH radical activity. Moreover, activity was also expressed as TEAC ( $\mu \mathrm{M} \mathrm{TE} / \mathrm{kg} \mathrm{FW})$.

\subsection{Angiotensin I-Converting Enzyme (ACE) Inhibitory Activity}

ACE inhibitory activities of extracts from berries were measured as described by Nagai and Nagashima (2006). $\mathrm{IC}_{50}$ value was defined as protein concentration of extract to inhibit $50 \%$ of ACE activity.

\subsection{Hyaluronidase Inhibitory Activity}

Hyaluronidase inhibitory activities of extracts from berries were investigated by Morgan-Elson method (Elson \& Morgan, 1933) with some modifications. A $0.02 \mathrm{ml}$ of extracts and $0.01 \mathrm{ml}$ of hyaluronidase from Ovine testes $(1,000 \mathrm{U} / \mathrm{ml}$; Wako Pure Chemicals Industries, Ltd., Osaka, Japan) were mixed in an Eppendorf tube and were pre-incubated at $37^{\circ} \mathrm{C}$ for $20 \mathrm{~min}$. Mixture was added $0.02 \mathrm{ml}$ of compound $48 / 80$ solution, and was incubated at the same condition. Enzyme reaction was started by addition of $0.05 \mathrm{ml}$ of hyaluronic acid solution. After incubation at $37{ }^{\circ} \mathrm{C}$ for $40 \mathrm{~min}$, reaction was stopped by addition of $0.02 \mathrm{ml}$ of $1.77 \mathrm{~N} \mathrm{NaOH}$ and $0.02 \mathrm{ml}$ of 0.8 $\mathrm{M}$ boric acid- $0.4 \mathrm{~N} \mathrm{NaOH}$ solution. Mixture was boiled for $3 \mathrm{~min}$, and then cooled in water. Mixture was added $0.6 \mathrm{ml}$ of $p$-dimethylaminobenzaldehyde solution. After incubation at $37{ }^{\circ} \mathrm{C}$ for $20 \mathrm{~min}$, absorbance of mixture was measured at $585 \mathrm{~nm}$, and inhibition rate was calculated by measuring amount of $N$-acetylglucosamine released. Test samples were replaced by buffer solution for control. Enzyme solution was replaced by buffer solution for blank. Percent inhibition was calculated as the following equation.

$$
\text { Inhibition }(\%)=[(\mathrm{A}-\mathrm{B})-(\mathrm{C}-\mathrm{D})] /(\mathrm{A}-\mathrm{B}) \times 100
$$

Where, A: control $\mathrm{OD}_{585}$, B: control blank $\mathrm{OD}_{585}, \mathrm{C}$ : sample $\mathrm{OD}_{585}$, D: sample blank $\mathrm{OD}_{585}$.

\subsection{Statistical Analysis}

Except for color analysis, each assay was repeated 3 times independently and results were reported as means \pm standard deviation (SD). 


\section{Results and Discussion}

\subsection{Overall Appearance}

First, overall appearance on everbearing strawberry cultivar, 'Dekoruju' berries was observed. Berries were glossy and colors of skins and pulps of berries were favorable. Particularly, it was red-fleshed and was bright in color. An eating quality was good and berries had a favorable balance of sweetness and acidity (sourness), as mentioned later because of higher sugar-acid ratio of berries. It seemed that taste was superior among other everbearing strawberry cultivars (Nagai et al., 2014; Okimura et al., 2011). Firmness of berries was observed and was fairly higher than other everbearing strawberry cultivars, 'Natsuakari' and 'Summerberry' (Okimura et al., 2011), suggesting high storability and transportability of berries. It is known that firmness of berries is influenced by pectin of cell wall polysaccharides in plants (Watkins et al., 1999). High firmness of 'Dekoruju' berries may be caused by increase of pectin viscosity. Moreover, firmness is directly affected by many factors such as cultivar, planting temperature, land elevation, maturity, size, and moisture content. Firmness is one of important factor for storability and transportability in commercial distribution.
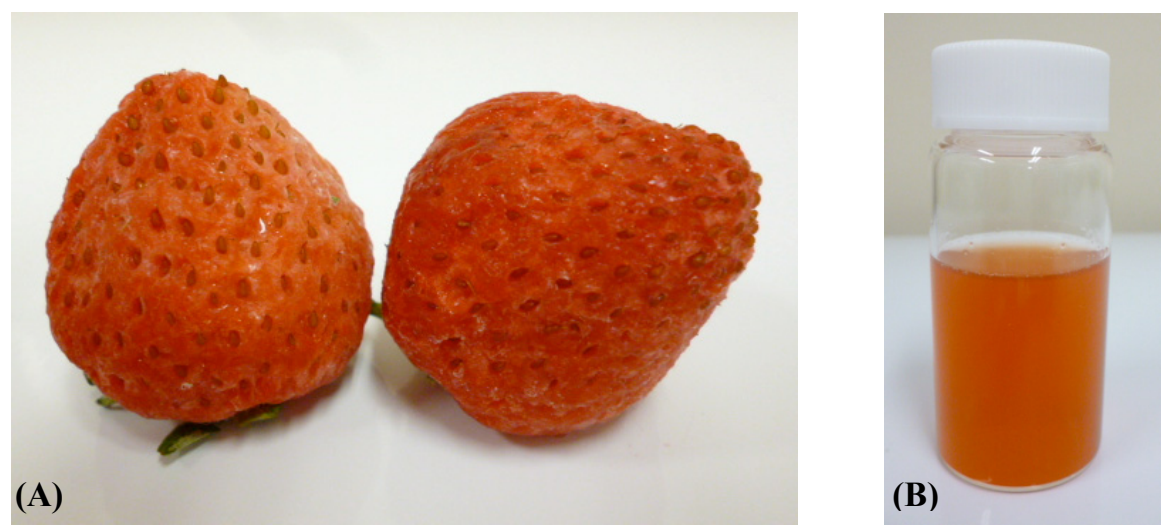

Figure 1. Everbearing strawberry cultivar, 'Dekoruju' berries (A) and extracts (B) prepared from berries

\subsection{Chemical Analysis}

Chemical parameters of everbearing strawberry cultivar, 'Dekoruju' berries were investigated. Contents of water, crude proteins, crude lipids, carbohydrates, and crude ashes were 86.1, 0.9, 0.1, 12.3, and 0.6\%, respectively (Table 1). In comparison to those of other strawberry cultivar berries (Kagawa, 2017; Nagai et al., 2014), 'Dekoruju' berries were remarkable high for contents of carbohydrates.

Berries were weighed, ground in a Potter-Elvehjem homogenizer with a motor-driven Teflon pestle in ice bath, and homogenates were used to the following tests. Specific gravity and $\mathrm{pH}$ were tested, and were 1.013 and 3.56 at $20{ }^{\circ} \mathrm{C}$, respectively (Table 1 ). Brix $\%$ was $11.5 \%$ at $20{ }^{\circ} \mathrm{C}$. Homogenates were then centrifuged at $30,000 \times \mathrm{g}$ for 30 min at $4{ }^{\circ} \mathrm{C}$. Supernatants were filtered with cheesecloth, and filtrates (extracts) were used to the following investigation. Titratable acidity of extracts was measured, and content was estimated to $0.79 \%$ as citric acid equivalent. That is, sugar-acid ratio was calculated to 14.6, suggesting its good eating quality. In comparison with those of everbearing strawberry cultivar, 'Summertiara' berries, Brix\% was high, but titratable acid content was low, showing higher sugar-acid ratio (Nagai et al., 2014). Total vitamin $B_{1}, B_{2}$, and $C$ contents of berries were investigated and were as follows: $0.35 \mathrm{mg} / 100 \mathrm{~g} \mathrm{FW}, 0.0037 \mathrm{mg} / 100 \mathrm{~g} \mathrm{FW}$, and $17.8 \mathrm{mg} / 100 \mathrm{~g} \mathrm{FW}$, respectively (Table 1). Compared to those of other strawberry cultivar berries (Kagawa, 2017; Nagai et al., 2014), vitamin $B_{1}$ content was fairly high, but vitamins $B_{2}$ and $C$ contents were low. Vitamin $C$ is an important quality attribute of strawberry cultivar berries. Cultivars and pre-harvest climate condition can be defined as crucial factors affecting vitamin C biosynthesis and accumulation (Cordenunsi et al., 2003). Spayed and Morris (1981) reported that strawberry fruit $\mathrm{cv}$. Cardinal had a higher rate of vitamin $\mathrm{C}$ accumulation when fruit reached its fully maturity. Olsson et al. (2004), and Kafkas et al. (2007) also reported that ascorbic acid concentration was generally higher in ripe berries compared to unripe ones.

Contents of total phenols, total flavonoids, and total anthocyanins on berries were measured, and results were as follows: $80.4 \mathrm{mg}$ ellagic acid equivalent/100 g FW, $50.6 \mathrm{mg}(+)$-catechin equivalent/100 g FW, $49.6 \mathrm{mg}$ P3G equivalent/100 g FW, respectively (Table 1). These contents were slightly lower than those of everbearing 
strawberry cultivar, 'Summertiara' berries (Nagai et al., 2014). Major phenolics of strawberry cultivar berries are ellagitannins, glycosylated dericatives of ellagic acid, $p$-coumaric acids, and anthocyanin (Häkkinen et al., 1999, 2000). Accumulation of phenolic compounds depends on cultivars, geographical position, growing temperature, and moisture contents of berries (Ayala-Zavala et al., 2004). Total anthocyanin contents are one of important parameter for assessing maturity of berries and attracting consumers (Cordenunsi et al., 2005). Contents increase with increasing degree of ripening (Ferreyra et al., 2007). Also, it is reported that greater anthocyanin biosynthesis and accumulation are induced on higher temperature and faster ripening (Ayala-Zavala et al., 2004; Zhang \& Watkins, 2005).

Table 1. Chemical parameters of everbearing strawberry cultivar, 'Dekoruju' berries

\begin{tabular}{|c|c|c|}
\hline \multicolumn{3}{|l|}{ Parameters } \\
\hline \multicolumn{2}{|l|}{ Water } & $86.1 \pm 0.20 \%$ \\
\hline \multicolumn{2}{|l|}{ Proteins } & $0.9 \pm 0.01 \%$ \\
\hline \multicolumn{2}{|l|}{ Lipids } & $0.1 \pm 0.03 \%$ \\
\hline \multicolumn{2}{|l|}{ Carbohydrates } & $12.3 \pm 0.04 \%$ \\
\hline \multicolumn{2}{|l|}{ Ashes } & $0.6 \pm 0.02 \%$ \\
\hline \multicolumn{2}{|c|}{ Specific gravity at $20{ }^{\circ} \mathrm{C}$} & $1.013 \pm 0.005$ \\
\hline \multicolumn{2}{|l|}{$\mathrm{pH}$ at $20{ }^{\circ} \mathrm{C}$} & $3.56 \pm 0.03$ \\
\hline \multicolumn{2}{|l|}{ Brix $\%$ at $20{ }^{\circ} \mathrm{C}$} & $11.5 \pm 0.3$ \\
\hline \multicolumn{2}{|c|}{ Titratable acid content } & $0.79 \pm 0.04 \%$ \\
\hline \multicolumn{2}{|l|}{ Sugar-acid ratio } & $14.6 \pm 0.07$ \\
\hline \multicolumn{2}{|l|}{ Total vitamin $\mathrm{B}_{1}$} & $0.35 \pm 0.02 \mathrm{mg} / 100 \mathrm{~g} \mathrm{FW}$ \\
\hline \multicolumn{2}{|l|}{ Total vitamin $\mathrm{B}_{2}$} & $0.0037 \pm 0.0002 \mathrm{mg} / 100 \mathrm{~g} \mathrm{FW}$ \\
\hline \multicolumn{2}{|l|}{ Total vitamin $\mathrm{C}$} & $17.8 \pm 0.3 \mathrm{mg} / 100 \mathrm{~g} \mathrm{FW}$ \\
\hline \multicolumn{2}{|l|}{ Total phenols } & $80.4 \pm 0.6^{*} \mathrm{mg} / 100 \mathrm{~g} \mathrm{FW}$ \\
\hline \multicolumn{2}{|l|}{ Total flavonoids } & $50.6 \pm 0.4 * * \mathrm{mg} / 100 \mathrm{~g} \mathrm{FW}$ \\
\hline \multicolumn{2}{|l|}{ Total anthocyanins } & $49.6 \pm 0.2 * * * \mathrm{mg} / 100 \mathrm{~g} \mathrm{FW}$ \\
\hline \multicolumn{3}{|l|}{ Color parameter } \\
\hline \multirow[t]{3}{*}{ surface } & $L^{*}$ & $26.31 \pm 1.01$ \\
\hline & $a^{*}$ & $28.42 \pm 2.70$ \\
\hline & $b^{*}$ & $18.31 \pm 1.06$ \\
\hline \multirow[t]{3}{*}{ homogenate } & $L^{*}$ & $20.63 \pm 0.20$ \\
\hline & $a^{*}$ & $13.54 \pm 0.18$ \\
\hline & $b^{*}$ & $11.02 \pm 0.15$ \\
\hline
\end{tabular}

Note. * ellagic acid equivalent, **(+)-catechin equivalent, *** P3G equivalent.

Berries were lyophilized and broken into pieces, and powder obtained was added to 10 volumes of boric acid-citric acid-trisodium phosphate buffer $(\mathrm{pH} \mathrm{2.0)}$. After extraction for $16 \mathrm{~h}$ at room temperature in dark, suspension was centrifuged at $7,740 \times \mathrm{g}$ for $10 \mathrm{~min}$. Supernatants were scanned at from 400 to $700 \mathrm{~nm}$ using a scanning spectrophotometer. From the result of absorption pattern at the range of 400 to $460 \mathrm{~nm}$, in particular at $430 \mathrm{~nm}$, it indicated presence of $\mathrm{P} 3 \mathrm{G}$ as the major anthocyanin in berries as shown in an arrow (Figure 2). Nagai et al. (2014) investigated effect of $\mathrm{pH}$ using wide $\mathrm{pH}$ range of buffers on anthocyanins from everbearing strawberry cultivar, 'Summertiara' berries. They reported presence of $\mathrm{P} 3 \mathrm{G}$ as the major anthocyanin of berries in the absorption pattern at $430 \mathrm{~nm}(\mathrm{pH} \mathrm{2.0)}$. Also, they reported changes in structures of P3G with increasing $\mathrm{pH}$.

\subsection{Color Measurement}

Colors on skins of everbearing strawberry cultivar, 'Dekoruju' berries were measured in twenty berries using a colorimeter. Colors were as vivid red (Figure 1A) and parameter was as follows: $L^{*}=26.31, a^{*}=28.42, b^{*}=$ 18.31 (Table 1). Color of homogenate was also vivid red (Figure 1B). Its parameter was as follows: $L^{*}=20.63$, $a^{*}=13.54, b^{*}=11.02$ (Table 1$)$. Compared to the colors of everbearing strawberry cultivar, 'Summertiara' berries (Nagai et al., 2014), the mean $a^{*}$ and $b^{*}$ values on surface (skins) of berries and the mean $L^{*}$ value were higher in homogenate, but the mean $a *$ in homogenate were lower, suggesting with deep red color on surface (skins) and less redness in central portion of berries. 


\subsection{Anti-oxidative Activity}

Anti-oxidative activities of extracts from berries were determined to evaluate inhibition effects at initiation stage of linoleic acid peroxidation. Extracts showed anti-oxidative activities and activities increased with an increasing concentration of extracts (Table 2). Activity of $1.0 \%$ extract was the same as that on $1.0 \mathrm{mM}$ ascorbic acid.

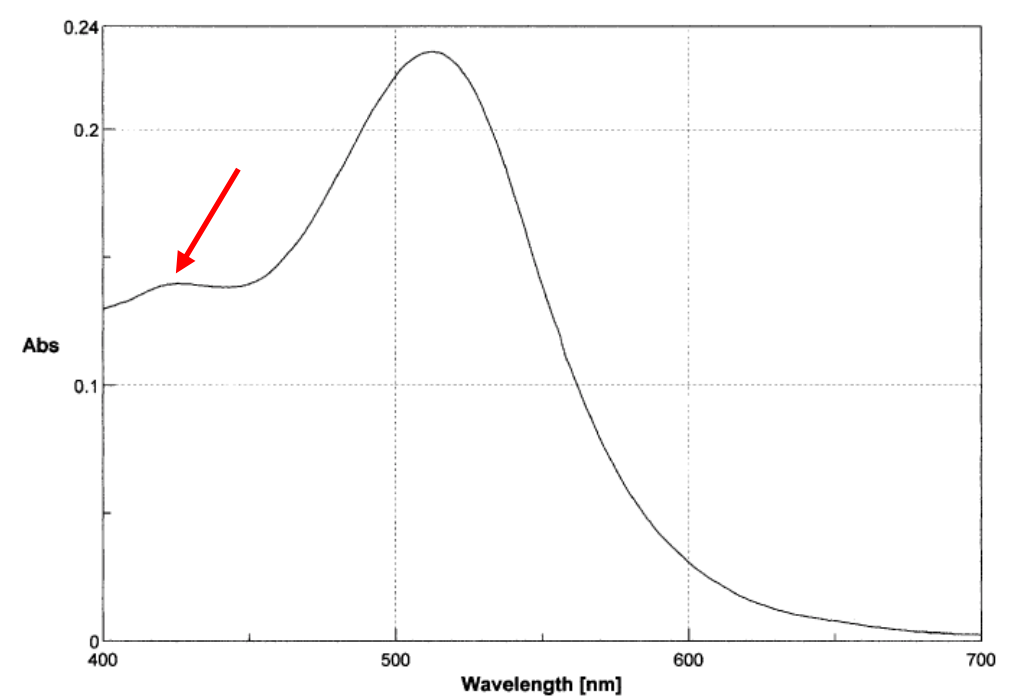

Figure 2. Visible rays absorption spectrum of extracts from everbearing strawberry cultivar, 'Dekoruju' berries

Table 2. Antioxidative activities of extracts prepared from everbearing strawberry cultivar, 'Dekoruju' berries

\begin{tabular}{|c|c|c|c|}
\hline \multirow{3}{*}{ Samples } & \multicolumn{3}{|c|}{ Absorbance at $500 \mathrm{~nm}$} \\
\hline & \multicolumn{3}{|c|}{ Time (min) } \\
\hline & 50 & 100 & 200 \\
\hline \multicolumn{4}{|c|}{ 'Dekoruju' extracts (\%) } \\
\hline 0.1 & $0.220 \pm 0.011$ & $0.464 \pm 0.024$ & $1.059 \pm 0.055$ \\
\hline 1.0 & $0.103 \pm 0.005$ & $0.189 \pm 0.012$ & $0.419 \pm 0.018$ \\
\hline 10 & $0.051 \pm 0.004$ & $0.100 \pm 0.009$ & $0.207 \pm 0.010$ \\
\hline 100 & $0.023 \pm 0.003$ & $0.021 \pm 0.003$ & $0.038 \pm 0.007$ \\
\hline \multicolumn{4}{|c|}{ Ascorbic acid (mM) } \\
\hline 1.0 & $0.022 \pm 0.001$ & $0.135 \pm 0.006$ & $0.469 \pm 0.027$ \\
\hline 5.0 & $0.016 \pm 0.001$ & $0.032 \pm 0.003$ & $0.090 \pm 0.008$ \\
\hline \multicolumn{4}{|c|}{$B H A(m M)$} \\
\hline 0.01 & $0.084 \pm 0.005$ & $0.120 \pm 0.008$ & $0.245 \pm 0.012$ \\
\hline 0.1 & $0.056 \pm 0.003$ & $0.090 \pm 0.006$ & $0.165 \pm 0.010$ \\
\hline 1.0 & $0.054 \pm 0.002$ & $0.057 \pm 0.003$ & $0.100 \pm 0.006$ \\
\hline \multicolumn{4}{|c|}{$B H T(m M)$} \\
\hline 0.01 & $0.082 \pm 0.003$ & $0.112 \pm 0.009$ & $0.248 \pm 0.011$ \\
\hline 0.1 & $0.058 \pm 0.004$ & $0.108 \pm 0.005$ & $0.173 \pm 0.008$ \\
\hline 1.0 & $0.044 \pm 0.002$ & $0.051 \pm 0.003$ & $0.093 \pm 0.005$ \\
\hline \multicolumn{4}{|c|}{$\alpha$-Tocopherol $(\mathrm{mM})$} \\
\hline 1.0 & 0.006 & $0.025 \pm 0.001$ & $0.028 \pm 0.002$ \\
\hline \multicolumn{4}{|c|}{ Trolox $(m M)$} \\
\hline 0.01 & $0.084 \pm 0.005$ & $0.094 \pm 0.006$ & $0.262 \pm 0.013$ \\
\hline 0.1 & $0.038 \pm 0.002$ & $0.051 \pm 0.003$ & $0.123 \pm 0.008$ \\
\hline 1.0 & $0.011 \pm 0.001$ & $0.031 \pm 0.002$ & $0.032 \pm 0.002$ \\
\hline Control & $0.379 \pm 0.008$ & $0.715 \pm 0.025$ & $1.406 \pm 0.041$ \\
\hline
\end{tabular}

Activity on $10 \%$ extract was higher than those on $0.01 \mathrm{mM}$ BHA and BHT, but was lower than those on $0.1 \mathrm{mM}$ BHA and BHT. The $100 \%$ extract almost completely inhibited linoleic acid peroxidation; activity on $100 \%$ 
extract was remarkably higher than those on $1.0 \mathrm{mM}$ BHA and BHT and 5.0 $\mathrm{mM}$ ascorbic acid, and was almost as high as those on $1.0 \mathrm{mM} \alpha$-tocopherol and trolox (Table 2).

\subsection{Superoxide Anion Radical Scavenging Activity}

Superoxide anion radical scavenging activities of extracts from berries were investigated. As a result, activities on 0.1 and $1.0 \%$ extracts were fairly low; these were not up to those on $0.01 \mathrm{mM}$ BHT and $1.0 \mathrm{mM}$ ascorbic acid (Table 3). On the other hand, activity on $10 \%$ extract was higher than that on $0.1 \mathrm{mM}$ BHA, but was slightly lower than those on $0.1 \mathrm{mM}$ BHT and $0.01 \mathrm{mM}$ trolox. The $100 \%$ extract showed the highest activity $(92.2 \%)$ in comparison with each positive control sample tested (Table 3). $\mathrm{IC}_{50}$ value was calculated about $12.02 \%$ as concentration of extracts from berries. Also, TEAC against this radical was estimated to $5.93 \times 10^{4} \mu \mathrm{M} \mathrm{TE} / \mathrm{kg}$ FW.

\subsection{Hydroxyl Radical Scavenging Activity}

Hydroxyl radical scavenging activities of extracts from berries were measured. The $0.1 \%$ extract did not shown this activity. For $10 \%$ extract, activity was low about $7.9 \%$ compared with those on 1.0 or $5.0 \mathrm{mM}$ ascorbic acid (Table 3). Activity for $10 \%$ extract was about $30.8 \%$, and even for $100 \%$ extract activity was not up to those of BHA, BHT, $\alpha$-tocopherol, and trolox tested. $\mathrm{IC}_{50}$ value was calculated to about $16.35 \%$ as concentration of extracts from berries. TEAC against this radical was $1.19 \times 10^{5} \mu \mathrm{M} \mathrm{TE} / \mathrm{kg} \mathrm{FW}$.

Table 3. Superoxide anion radical, hydroxyl radical, and DPPH radical scavenging activities of extracts prepared from everbearing strawberry cultivar, 'Dekoruju' berries

\begin{tabular}{|c|c|c|c|}
\hline \multirow{2}{*}{ Samples } & \multicolumn{3}{|c|}{ Scavenging activity (\%) } \\
\hline & Superoxide anion radical & Hydroxyl radical & DPPH radical \\
\hline \multicolumn{4}{|c|}{ 'Dekoruju'extracts (\%) } \\
\hline 0.1 & $0.4 \pm 0.06$ & 0.0 & $24.7 \pm 0.37$ \\
\hline 1.0 & $4.5 \pm 0.11$ & $7.9 \pm 0.19$ & $33.7 \pm 0.89$ \\
\hline 10 & $41.6 \pm 0.95$ & $30.8 \pm 0.71$ & $79.5 \pm 1.93$ \\
\hline 100 & $92.2 \pm 2.16$ & $54.2 \pm 2.29$ & $>100$ \\
\hline \multicolumn{4}{|c|}{ Ascorbic acid $(m M)$} \\
\hline 1.0 & $14.7 \pm 0.20$ & $13.2 \pm 0.21$ & $3.1 \pm 0.04^{*}$ \\
\hline 5.0 & $89.9 \pm 5.31$ & $17.6 \pm 0.71$ & $34.1 \pm 2.01 * *$ \\
\hline \multicolumn{4}{|c|}{$B H A(m M)$} \\
\hline 0.01 & $29.3 \pm 0.52$ & $59.1 \pm 0.78$ & $5.5 \pm 0.04$ \\
\hline 0.1 & $36.4 \pm 0.91$ & $93.3 \pm 1.39$ & $17.5 \pm 0.36$ \\
\hline 1.0 & $51.9 \pm 1.36$ & $95.2 \pm 1.44$ & $72.7 \pm 3.58$ \\
\hline \multicolumn{4}{|c|}{$B H T(m M)$} \\
\hline 0.01 & $11.7 \pm 0.19$ & $82.8 \pm 0.91$ & $3.9 \pm 0.03$ \\
\hline 0.1 & $46.6 \pm 1.02$ & $97.6 \pm 1.55$ & $7.9 \pm 0.08$ \\
\hline 1.0 & $48.4 \pm 1.17$ & $>100$ & $31.7 \pm 0.76$ \\
\hline \multicolumn{4}{|c|}{$\alpha$-Tocopherol $(\mathrm{mM})$} \\
\hline 1.0 & $52.6 \pm 4.18$ & $67.6 \pm 4.34$ & $87.6 \pm 2.75$ \\
\hline \multicolumn{4}{|c|}{ Trolox $(m M)$} \\
\hline 0.01 & $46.4 \pm 0.98$ & $81.5 \pm 0.63$ & $0.1 \pm 0.01$ \\
\hline 0.1 & $58.1 \pm 1.12$ & $91.8 \pm 1.17$ & $17.9 \pm 0.20$ \\
\hline 1.0 & $76.1 \pm 1.89$ & $>100$ & $86.3 \pm 3.27$ \\
\hline
\end{tabular}

Note. * $0.1 \mathrm{mM}$ ascorbic acid; ** $1.0 \mathrm{mM}$ ascorbic acid.

\subsection{DPPH Radical Scavenging Activity}

DPPH radical scavenging activities of extracts from berries were determined. As a result, each sample exhibited activity and these activities increased with increasing concentration of extracts. Activity for $0.1 \%$ extract was fairly higher than those on $1.0 \mathrm{mM}$ ascorbic acid, and 0.01 and $0.1 \mathrm{mM} \mathrm{BHA,} \mathrm{BHT,} \mathrm{and} \mathrm{trolox} \mathrm{(Table} \mathrm{3).} \mathrm{For}$ $1.0 \%$ extract possessed the same activity as those on $5.0 \mathrm{mM}$ ascorbic acid and $1.0 \mathrm{mM}$ BHT. Activity for $10 \%$ 
extract was higher than that on $1.0 \mathrm{mM} \mathrm{BHA}$, although activity did not reach those on $1.0 \mathrm{mM} \alpha$-tocopherol and trolox. On the contrary, activity of $100 \%$ extract extremely high in comparison to each positive control sample tested. Extracts perfectly inhibited this radical. $\mathrm{IC}_{50}$ value was calculated to about $5.21 \%$ as concentration of extracts from berries. TEAC against this radical was $1.07 \times 10^{7} \mu \mathrm{M}$ TE $/ \mathrm{kg}$ FW. It is known that DPPH radical scavenging activity is correlated with total phenol contents. It suggests that highest activity against DPPH radicals of the berries attribute to high contents of total phenols (Table 1).

\subsection{ACE Inhibitory Activity}

ACE inhibitory activities of extracts prepared from berries were measured. Extract for $0.1 \%$ did not exhibited activity at all. However, activities tended to increase extract concentration-dependently. Extract for $100 \%$ had strong activity about $62.7 \%$ against ACE (Table 4). Protein content of extract was measured by method of Lowry et al. (1951). $\mathrm{IC}_{50}$ value against ACE activity was calculated to $2.79 \mathrm{mg}$ protein $/ \mathrm{ml}$.

\subsection{Hyaluronidase Inhibitory Activity}

Patients with allergy are increasing yearly. Many species of allergic symptoms exists as follows: alimentary allergy (food allergy), asthma bronchiale, atopic dermatitis, and pollinosis (hay fever). It is known four classes from type I to IV as allergic responses on mechanism of immunological involvement. Hyaluronidase exists in some organs and fluids of body, and is relased from mast cells with histamin as chemical mediators. It hydrolyzes hyaluronic acid in extracellular matrix of connective tissue. Hyaluronidase is involved not only in action that induces inflammation but also in permeability of vascular system. Hyaluronidase is responsible for process causing allergic reactions and inflammation. It is well known that hyaluronidase inhibitory activity and suppression of histamine relase have strong positive correlation. So, effect of hyaluronidase inhibition is used to evaluate anti-allergic activity. At present, research on the phytochemical compositions and anti-allergic activities of food materials are progressing (Kaneda et al., 1998; Yamamoto et al., 2004). Hyaluronidase inhibitory activities of extracts from berries were determined. Surprisingly, extracts below $50 \%$ did not shown activities at all, but extract for $100 \%$ possessed activity about $67.6 \%$ (Table 4). Sodium cromoglicate is used as one of commercially available anti-allergic drugs (chemical mediator release inhibitors) against atopic dermatitis based on food allergies, allergic rhinitis, allergic conjunctivitis and so on. Hyaluronidase inhibitory activity was measured using sodium cromoglicate (purchased from Wako Pure Chemical Industries, Ltd., Osaka, Japan) using the same method, and then a standard curve was prepared. As a result, activity for $100 \%$ extract corresponded to that of $0.783 \mu \mathrm{M}(0.783 \mu \mathrm{M}$ sodium cromoglicate equivalent). These results indicated that anti-allergic and anti-inflammatory effects were expected by intake of fresh 'Dekoruju' berries.

Table 4. ACE and hyaluronidase inhibitory activities of extracts prepared from everbearing strawberry cultivar, 'Dekoruju' berries

\begin{tabular}{lll}
\hline Extracts (\%) & ACE inhibition (\%) & Hyaluronidase inhibition (\%) \\
\hline 0.1 & 0.0 & 0.0 \\
1.0 & $9.5 \pm 0.2$ & 0.0 \\
10 & $27.0 \pm 2.1$ & 0.0 \\
50 & $46.2 \pm 3.0$ & 0.0 \\
100 & $62.7 \pm 5.1$ & $67.6 \pm 3.5$ \\
\hline
\end{tabular}

From the present study, it found that everbearing strawberry cultivar, 'Dekoruju' berries were foods rich in vitamins $B_{1}$ and $C$ and phenol compounds such as anthocyanins and flavonoids. Vitamin $C$ and phenol compounds are one of powerful scavengers against reactive oxygen species and free radicals such as superoxide anion radicals, hydroxyl radicals, hydrogen peroxide, and singlet oxygen. In fact, extracts prepared from berries possessed remarkable high scavenging activities against superoxide anion radicals, hydroxyl radicals, and DPPH radicals, compared to commercially available natural or synthetic antioxidants such as BHA, BHT, and $\alpha$-tocopherol. Formation and increase of these radicals in human body directly or indirectly cause degenerative diseases and chronic diseases such as cancer, cardiac affection, diabetes, and hypertension. Anti-oxidative function to scavenge reactive oxygen species plays the most important role in early stages of biological defense mechanism to suppress carcinogenesis in body. Extracts showed the highest inhibitory activity against linoleic acid peroxidation. Moreover, extracts exhibited the foremost inhibitory activities against not only ACE but also hyaluronidase, suggesting beneficial effects on anti-hypertension and anti-allergy. It is hereafter deeply anxious 
to maintain and promote health, and to rejuvenate body or to prevent and treat diseases through conventional daily meals more and more.

\section{Conclusion}

Everbearing strawberry cultivar, 'Dekoruju' berries had a favorable balance of sweetness and sourness because of higher sugar-acid ration of berries. These were foods rich in vitamin $\mathrm{B}_{1}$ and phenol compounds such as anthocyanins and flavonoids. Extracts prepared from berries, especially in 100\% concentration, almost completely inhibited linoleic acid peroxidation under the condition tested. These showed extremely high scavenging activities against specially superoxide anion and DPPH radicals in comparison with all commercially available natural or synthetic antioxidants tested. These also exhibited the foremost inhibitory activities against not only ACE but also hyaluronidase, suggesting beneficial effects on anti-hypertension, anti-allergy, and anti-inflammatory. The present study indicated that fresh 'Dekoruju' berries may be considered as good sources of natural antioxidants such as phenol compounds (anthocyanins and flavonoids), and may contribute to maintain and promote health and to help protect body against chronic diseases and an allergy disease.

\section{References}

Ayala-Zavala, J. F., Wang, S. Y., Wang, C. Y., \& González-Aguilar, G. A. (2004). Effect of storage temperature on antioxidant capacity and aroma compounds in strawberries fruit. LWT-Food Science and Technology, 37, 687-695. https://doi.org/10.1016/j.lwt.2004.03.002

Bakker, J., Bridle, P., \& Bellworthy, S. J. (1994). Strawberry juice colour: A study of the quantitative and qualitative pigment composition of juices from 39 genotypes. Journal of the Science of Food and Agriculture, 64, 31-37. https://doi.org/10.1002/jsfa.2740640106

Basu, A., Wilkinson, M., Penugonda, K., Simmons, B., Betts, N. M., \& Lyons, T. J. (2009). Freeze-dried strawberry powder improves lipid profile and lipid peroxidation in women with metabolic syndrome: Baseline and post intervention effects. Nutrition Journal, 8, 43. https://doi.org/10.1186/1475-2891-8-43

Chatterjee, A., Yasmin, T., Badchi, D., \& Stohs, S. J. (2004). Inhibition of Helicobacter pylori in vitro by various berry extracts, with enhanced susceptibility to clarithromycin. Molecular and Cellular Biochemistry, 265, 19-26. https://doi.org/10.1023/B:MCBI.0000044310.92444.ec

Cordenunsi, B. R., Genovese, M. I., Nascimento, J. R. O., Hassimotto, N. M. A., Dos Santos, R. J., \& Lajolo, F. M. (2005). Effects of temperature on the chemical composition and antioxidant activity of three strawberry cultivars. Food Chemistry, 91, 113-121. https://doi.org/10.1016/j.foodchem.2004.05.054

Cordenunsi, B. R., Nascimento, J. R. O., \& Lajolo, F. M. (2003). Physico-chemical changes related to quality of five strawberry fruit cultivars during cool-storage. Food Chemistry, 83, 167-173. https://doi.org/10.1016/ S0308-8146(03)00059-1

Elson, L. A., \& Morgan, W. T. J. (1933). A colorimetric method for the determination of glucosamine and chondrosamine. Biochemical Journal, 27, 1824-1828. https://doi.org/10.1042/bj0271824

Ferreyra, R. M., Vina, S. Z., Mugridge, A., \& Chaves, A. R. (2007). Growth and ripening season effects on antioxidative capacity of strawberry cultivar Selva. Scientia Horticulturae, 112, 27-32. https://doi.org/ 10.1016/j.scienta.2006.12.001

Gil, M. I., Holcroft, D. M., \& Kader, A. A. (1997). Changes in strawberry anthocyanins and other polyphenols in response to carbon dioxide treatments. Journal of Agricultural and Food Chemistry, 45, 1662-1667. https://doi.org/10.1021/jf960675e

Häkkinen, S. H., Kärenlampi, S. O., Heinonen, I. M., Mykkänen, H. M., \& Törrönen, A.R. (1999). Content of the flavonols quercetin, myricetin, and kaempferol in 25 edible berries. Journal of Agricultural and Food Chemistry, 47, 2274-2279. https://doi.org/10.1021/jf9811065

Häkkinen, S. H., Kärenlampi, S. O., Mykkänen, H. M., Heinonen, I. M., \& Törrönen, A. R. (2000). Ellagic acid content in berries: Influence of domestic processing and storage. European Food Research and Technology, 212, 75-80. https://doi.org/10.1007/s002170000184

Hannum, S. M. (2004). Potential impact of strawberries on human health: A review of science. Critical Reviews in Food Science and Nutrition, 44, 1-17. https://doi.org/10.1080/10408690490263756

Huang, W. Y., Cai, Y. Z., \& Zhang, Y. (2010). Natural phenolic compounds from medicinal herbs and dietary plants: Potential use for cancer prevention. Nutrition and Cancer, 62, 1-20. https://doi.org/10.1080/ 01635580903191585 
Imada, S. (2006). Production of strawberries in summer and autumn under the cool climate of the Tohoku region. Proceedings of Vegetable and Tea Science, 3, 61-66.

Jin, P., Wang, Y. S., Wang, C. Y., \& Zheng, Y. (2011). Effect of cultural system and storage temperature on antioxidant capacity and phenolic compounds in strawberries. Food Chemistry, 124, 262-270. https://doi.org/10.1016/j.foodchem.2010.06.029

Kafkas, E., Kosar, M., Paydas, S., \& Baser, K. S. C. (2007). Quality characteristics of strawberry genotypes at different maturation stages. Food Chemistry, 100, 1229-1236. https://doi.org/10.1016/j.foodchem.2005. 12.005

Kagawa, A. (2017). Standard Tables of Food Composition in Japan 2017. Tokyo: Kagawa Nutrition University Publishing Division.

Kaneda, T., Akiyama, H., Yanagida, A., Tanabe, M., Goda, Y., Toyoda, M., ... Saito, Y. (1998). Inhibitory effects of apple polyphenol on induced histamine release from RBL-2H3 cells and rat mast cells. Bioscience, Biotechnology, and Biochemistry, 62, 1284-1289. https://doi.org/10.1271/bbb.62.1284

Kikoku, Y., Fukuhara, K., Saito, I., \& Oota, H. (1995). Identification and high performance liquid chromatographic determination of strawberry anthocyanin pigments. Journal of the Japanese Society for Food Science and Technology, 42, 118-123. https://doi.org/10.3136/nskkk.42.118

Kim, D.-O., Chun, O. K., \& Kim, Y. J. (2003). Quantification of polyphenolics and their antioxidant capacity in fresh plums. Journal of Agricultural and Food Chemistry, 51, 6509-6515. https://doi.org/10.1021/jf0343074

Lansky, E. P., \& Newman, R. A. (2007). Punica granatum (Pomegranate) and its potential for preservation and treatment of inflammation and cancer. Journal of Ethnopharmacology, 109, 177-206. https://doi.org/ 10.1016/j.jep.2006.09.006

Lopes-da-Silva, F., Escribano-Bailón, M. T., Pérez Alonso, J. J., Rivas-Gonzalo, J. C., \& Santos-Buelga, C. (2007). Anthocyanin pigments in strawberry. LWT-Food Science and Technology, 40, $374-382$. https://doi.org/10.1016/j.lwt.2005.09.018

Lowry, O. H., Rosebrough, N. J., \& Farr, A. L. (1951). Protein measurement with the Folin phenol reagent. Journal of Biological Chemistry, 193, 265-275.

Meyers, K. J., Watkins, C. B., Pritts, M. P., \& Liu, R. H. (2003). Antioxidant and antiproliferative activities of strawberries. Journal of Agricultural and Food Chemistry, 51, 6887-6892. https://doi.org/10.1021/ jf034506n

Mitcham, R. J. (2004). Strawberries. In K. C. Gross, C. Y. Wang, \& M. E. Saltveit (Eds.), The commercial Storage of Fruits, Vegetables, and Florist and Nursery Crops. U.S. Department of Agriculture, Agricultural Research Service, Beltsville Area, Agriculture Handbook.

Nagai, T., \& Nagashima, T. (2006). Functional properties of dioscorin, a soluble viscous protein from Japanese yam (Dioscorea opposita Thunb.) tuber mucilage tororo. Zeitschrift für Naturforschung C, 61, $792-798$. https://doi.org/10.1515/znc-2006-11-1204

Nagai, T., Tamai, M., Sato, M., Tanoue, Y., Kai, N., \& Suzuki, N. (2014). Characterization and functional properties of new everbearing strawberry (Fragaria $x$ ananassa Duch.) cultivar, 'Summertiara' berries. Functional Foods in Health and Disease, 4, 1-22.

Nakamura, K., Takita, T., Watanabe, T., Sato, H., \& Wada, M. (1998). In K. Nakamura, T. Takita, \& T. Watanabe (Eds.), Experimental Book in Basic Food Science (pp. 137-144). Tokyo: Sankyo Shuppan.

Oki, T., \& Suda, I. (2008). Anthocyanin. In Science of Functional Foods Editorial Committee (Ed.), Science of Functional Foods (pp. 1057-1066). Tokyo: Tech Information s.c.

Okimura, M., Okamoto, K., Honjo, M., Yui, S., Matsunaga, H., Ishii, T., ... Kawazu, Y. (2011). Breeding of new everbearing strawberry cultivars, 'Natsuakari' and 'Dekoruju'. Horticultural Research (Japan), 10, $121-126$. https://doi.org/10.2503/hrj.10.121

Olsson, M. E., Ekvall, J., Gustavsson, K. E., Nilsson, J., Pillai, D., Sjoholm, I., ... Nyman, M. G. L. (2004). Antioxidants, low molecular weight carbohydrates, and total antioxidant capacity in strawberries (Fragaria $x$ ananassa): Effects of cultivar, ripening, and storage. Journal of Agricultural and Food Chemistry, 52, 2490-2498. https://doi.org/10.1021/jf030461e 
Opara, U. L., \& Al-Ani, M. R. (2010). Antioxidant contents of pre-packed fresh-cut versus whole fruit and vegetables. British Food Journal, 112, 797-810. https://doi.org/10.1108/00070701011067424

Oszmianski, J., \& Wojdylo, A. (2009). Comparative study of phenolic content and antioxidant activity of strawberry puree, clear, and cloudy juices. European Food Research and Technology, 228, 623-631. https://doi.org/10.1007/s00217-008-0971-2

Seeram, N. P., Adams, L. S., Zhang, Y., Lee, R., Sand, D., Scheuller, H. S., \& Heber, D. (2006). Blackberry, black raspberry, blueberry, cranberry, red raspberry, and strawberry extracts inhibit growth and stimulate apoptosis of human cancer cells in vitro. Journal of Agricultural and Food Chemistry, 54, 9329-9339. https://doi.org/10.1021/jf061750g

Slinkard, K., \& Singleton, V. L. (1977). Total phenol analysis: Automation and comparison with manual methods. American Journal of Enology and Viticulture, 28, 49-55.

Sone, K., Mochizuki, T., \& Noguchi, Y. (1999). Variations in ascorbic acid content among strawberry cultivars and their harvest times. Journal of the Japanese Society for Horticultural Science, 68, 1007-1014. https://doi.org/10.2503/jjshs.68.1007

Spayd, S. E., \& Morris, J. R. (1981). Physical and chemical characteristics of puree from one-over harvested strawberries. Journal of the American Society for Horticultural Science, 106, 101-105.

Stoner, G. D., Kresty, L. A., Carlton, P. S., Sliglin, J. C., \& Morse, M. A. (1999). Isothiocyanates and freeze-dried strawberries as inhibitors of esophageal cancer. Toxicological Sciences, 52(Supplement), 95-100. https://doi.org/10.1093/toxsci/52.2.95

Takahashi, H. (2006). Present states and prospects of everbearing strawberry breeding in Northern Japan. Horticultural Research (Japan), 5, 213-217. https://doi.org/10.2503/hrj.5.213

Tamura, H., Takada, M., \& Yoshida, Y. (1995). Pelargonidin 3-o-(6-o-malonyl- $\beta$-D-glucoside) in Fragaria $x$ ananassa Duch. cv. Nyoho. Bioscience, Biotechnology, and Biochemistry, 59, 1157-1158. https://doi.org/ 10.1271/bbb.59.1157

The Vitamin Society of Japan. (1990). Vitamin Handbook (pp.139-140). Kyoto: Kagakudojin.

Watkins, C. B., Manzano-Mendez, J. E., Nock, J. F., Zhang, J. Z., \& Maloney, K. E. (1999). Cultivar variation in response of strawberry fruit to high carbon dioxide treatment. Journal of the Science of Food and Agriculture, 79, 886-890. https://doi.org/10.1002/(SICI)1097-0010(19990501)79:6<886::AID-JSFA303> 3.0.CO;2-0

Wedge, D. E., Meepagala, K. M., Magee, J. B., Smith, S. H., Huang, G., \& Larcom, L. L. (2001). Anticarcinogenic activity of strawberry, blueberry, and raspberry extracts to breast and cervical cancer cells. Journal of Medicinal Food, 4, 49-51. https://doi.org/10.1089/10966200152053703

Yamamoto, T., Yoshimura, M., Yamaguchi, F., Kouchi, T., Tsuji, R., Saito, M., ... Kikuchi, M. (2004). Anti-allergic activity of naringenin chalcone from a tomato skin extract. Bioscience, Biotechnology, and Biochemistry, 68, 1706-1711. https://doi.org/10.1271/bbb.68.1706

Yoshida, Y., Koyama, N., \& Tamura, H. (2002). Color and anthocyanin composition of strawberry fruit: Changes during fruit development and differences among cultivars, with special references to the occurrance of pelargonidin 3-malonylglucoside. Journal of the Japanese Society for Horticultural Science, 71, 355-361. https://doi.org/10.2503/jjshs.71.355

Yui, S., \& Honjo, M. (2007). Trend on the development of everbearing strawberry cultivars. Retrieved from http:/www.naro.affrc.go.jp/training/files/2007-12material.pdf

Zhang, J. J., \& Watkins, C. B. (2005). Fruit quality, fermentation products, and activities of associated enzymes during elevated $\mathrm{CO}_{2}$ treatment of strawberry fruit at high and low temperatures. Journal of the American Society for Horticultural Science, 130, 124-130.

\section{Copyrights}

Copyright for this article is retained by the author (s), with first publication rights granted to the journal.

This is an open-access article distributed under the terms and conditions of the Creative Commons Attribution license (http://creativecommons.org/licenses/by/4.0/). 